\title{
Comment on Chinese Limited Liability Company's Stock Rights Transfer System ------In perspective of Article 72 in Company Law of the People's Republic of China
}

\author{
Shanling Liu \\ Department of Politics \& Law, Dezhou University, Dezhou 253023, China \\ E-mail: liushanling666@163.com
}

\begin{abstract}
Article 72 in Company Law of the People's Republic of China (Company Law for short) regulates the limited liability company's stock rights transfer under common conditions. However, it can not solve all practical issues effectively. In perspective of Article 72 of Company Law, this paper probes into the progresses and the defects of limited liability company's stock rights transfer system, and analyzes some hot issues, including how some shareholders actualize their preemptive right to purchase the stock rights in practice, and how to evaluate the effect of articles of association as there is a conflict concerning stock rights transfer with Company Law, with the hope of benefiting the study of limited liability company's stock rights transfer and the settlement of practical corporate issues.
\end{abstract}

Keywords: Limited liability company, Stock rights transfer system, Validity of articles of association

Article 72 in Company Law of the People's Republic of China (Company Law for short) regulates the limited liability company's stock rights transfer under common conditions. This article is more accurate and more practical than relevant regulations in former Company Law. It will benefit the healthy development of China's company system and the settlement of corporate conflicts, which will undoubtedly drive the update and the progress of idea of Company Law. However, as more conflicts concerning the stock rights transfer of limited liability company and people's deepening recognition to company system, amounts of new issues emerge. Article 72 of Company Law can not solve all relevant issues in practice effectively.

In perspective of Article 72 of Company Law, this paper probes into the progresses and the defects of limited liability company's stock rights transfer system, and analyzes some hot issues, including how some shareholders actualize their preemptive right to purchase the stock rights in practice, and how to evaluate the effect of articles of association as there is a conflict concerning stock rights transfer with Company Law, with the hope of benefiting the study of limited liability company's stock rights transfer and the settlement of practical corporate issues.

\section{The regulation of Company Law on limited liability company (limited company for short) transferring stock rights}

According to Article 72 of Company Law, the first term regulates that all or some of the stock rights of the shareholders of a limited liability company may be transferred between the shareholders. Literally, it uses the word "may", which means that Company Law does not set compulsory limits for transferring stock rights between shareholders. It is a random term. Therefore, under the condition of without restrictive regulations in article of association, only when shareholders reach an agreement, they can transfer stock rights internally and other shareholders can not necessarily agree. To transfer stock rights internally is free in a sense.

The second term and the third term use the word "shall" respectively. They set strict procedure restriction on external transfer of stock rights (Xudong Zhao, 2003, p16). Whether this procedure restriction is a kind of legal compulsory regulation? If it is, the behavior that breaches this term in transferring stock rights externally is invalid. There is no other choice. But in practice, other shareholders may recognize and give up the preemptive right to purchase or can not afford the stock rights, what makes the activity that breaches this term in transferring stock rights externally valid. Therefore, it is not a compulsory term in law.

However, in order to actualize the interest balance of shareholders who transfer stock rights and the shareholders who continue to hold stock rights, legalization sets up three rules, namely "the approval right of other shareholders", "the compulsory obligation of purchase", and "the preemptive right of purchase", for the sake of maintaining the people combination of limited company.

\subsection{The approval right of other shareholders}

For this Article, two issues deserve notices. Firstly, "the approval of more than half of the other shareholders" means that the transfer of stock rights is based on the number of shareholders instead of the quantity of stocks. It is an 
exception of "capital-based decision principle". Secondly, the regulation of "more than half of" focuses on "the other shareholders" and the shareholders who transfer stock rights should follow the avoidance principle, according to the Company Law. Apparently, this Article in Company Law adopts the avoidance principle of stakeholders in decision making.

This change in Company Law means to embody the people combination of limited liability and protect the interests of small and medium-sized shareholders. The author holds different opinions. This change presents a higher requirement for the number of shareholders who agree the decision, improving the legal entrance for transferring stock rights externally. In detail:

Suppose $\mathrm{X}$--- shareholders who plan to transfer stock rights, $\mathrm{Y}$--- other shareholders who agree to transfer stock rights externally (agreement shareholders for short), and $\mathrm{Z}$--- other shareholders who disagree to transfer stock rights externally (disagreement shareholders for short".

(1) In the old Company Law, requirements for the number of shareholders who plan to transfer stock rights and the number of shareholders who agree to transfer stock rights externally are:

$\mathrm{X}+\mathrm{Y}>(\mathrm{X}+\mathrm{Y}+\mathrm{Z}) / 2$, namely $\mathrm{X}+\mathrm{Y}>\mathrm{Z}$;

(2) In today's Company Law, requirements for the number of shareholders who plan to transfer stock rights and the number of shareholders who agree to transfer stock rights externally are:

$\mathrm{Y}>(\mathrm{Y}+\mathrm{Z}) / 2$, namely $\mathrm{Y}>\mathrm{Z}$.

Apparently, today's Company Law puts forward a higher requirement for the number of shareholders who agree the transfer of stock rights, which adds more difficulties on transferring stock rights externally. A quite lot of shareholders choose to transfer stock rights externally because the poor interpersonal relationship between shareholders or the suppression from controlling shareholders. They can not get expected economic interests. To make some shareholders to avoid decision making is not the real mean of law makers. The Article 35 in old Company Law is more reasonable in a sense.

\subsection{The compulsory obligation of purchase}

According to the new Company Law, in transferring stock rights externally, other shareholders must make a choice between agreeing the transfer and purchasing the stock rights. Therefore, the purchase is an obligation under a special condition. This Article means to set up restrictions for transferring stock rights externally in procedures, for the sake of protecting the legal rights of other shareholders. Meanwhile, in order to maintain the principle of free transfer of stock rights, impose a special obligation on shareholders who disagree with the external transfer of stock rights, which reflects the interest balance between the shareholders who transfer stock rights and the other shareholders.

The new Company Law does not regulate the price of shareholders who disagree with the external transfer in purchasing the transferred stocks. In practice, the shareholders who intend to transfer stock rights externally price the stock highly. Then, the shareholders who disagree with the transfer can not afford the price. As a matter of fact, in the author's opinion, as other shareholders disagree with the transfer, they can purchase these stocks by themselves or be allowed to ask the third party to make the purchase. Then, it can stop the possibility of other unfamiliar joiners in the company. By this way, it ensures the free transfer of stock rights and maintains the trust between shareholders. As for the price, it can be regulated by the articles of association or other rules. As shareholders intend to transfer stock rights externally, the company or other shareholders can predetermine a price standard or calculation formula for the purchase. By this way, it can effectively avoid the illegal transfer between shareholders and external parties (Xudong Zhao, 2003, p16).

Many countries have more perfect regulations concerning this condition.

For example, the Article 5 in the Company Law of France regulates: “..... if the company does not agree with the transfer, shareholders must purchase or ask others to purchase these stocks at the price established by the Article 1843-4 of Civil Law in three months since the refuse." The fifth term of Article 19 in the Limited Company Law of Japan also regulates that: "as other shareholders disagree with the transfer, the shareholder meeting can ask a party to purchase the stocks at the price established by the fourth term of Article 204 in the Business Law of Japan." (Baoshu Wang, 2004, p34)

These regulations balance well the conflict of legal values between shareholders' freedom of dealing with stock rights and maintenance of limited company's people combination. The Company Law of China can learn a lot from them.

\subsection{The preemptive right of purchase}

The second term of Article 72 in Company Law: Under the same conditions, the other shareholders have a preemptive right to purchase the stock rights to be transferred upon their approval.

It does not regulate when and how other shareholders execute their preemptive right to purchase the stock rights. In 
order to drive the obligee to exercise the right and protect the interests of shareholders who transfer the stock rights, laws should regulate the deadline for the exercise of preemptive right. If the obligee does not exercise the right, it can be regarded as giving up purchasing the stock rights to be transferred. For this point, some countries, such as France, regulates a term of three months. If the court allows, the time can be six months at most. Therefore, company participators can complement this issue by article of association. For example, other shareholders enjoy the preemptive right to purchase the stock rights for three months, less or more. Without exercising the right in the period, they are regarded as giving up the right of purchase. The shareholders can transfer the stock rights to the third party (Weili Huang, 2006, p153).

Secondly, the "same condition" is the essential element for the exercise of preemptive right. As for the standard of "same condition", there are disputes in practice. In the author's opinion, the best way is to establish a way judging whether other shareholders prefer to purchase the stock rights to be transferred or not before signing a transfer contract between the shareholder who transfers stock rights and the third party, based on with confirming the standard for "same condition" (Xudong Zhao, 2003, p8). In practice, the transfer happens under the two conditions. Firstly, the assignor presents the condition of transfer. Under this condition, the assignor informs it to other shareholders by written files, together with other necessary materials. Other shareholders must give feedback in written files in thirty days. If other shareholders would not like to purchase, they should not claim for the preemptive right to purchase as the third party signs a transfer contract with the assignor at the same condition or better condition. Surely, as the assignor decreases the condition, he or she should inform other shareholders and confirms whether they want to purchase or not. Secondly, the third party presents the condition of transfer. Under this condition, the assignor should inform the transfer and the condition to other shareholders, and confirms whether they want to purchase or not, before promising to the transfer. If other shareholders want to purchase the stock rights, they should inform the assignor in three days since they receive the written notice. Then, the assignor should refuse it even if others present better conditions. Besides, in the transfer process, the assignor or the third party may present a higher price for the stock to be transferred. They mean to exclude other shareholders. At this circumstance, other shareholders can question the stock price. All related parties must evaluate the company's assets and debts before establishing the price of stock to be transferred.

Thirdly, whether shareholders' preemptive right to purchase can be exercised partially is always a confusing problem in the law field. The Company Law does not regulate it clearly. In the author's opinion, shareholders' preemptive right can not be exercised partially. First of all, according to the term "Under the same conditions, the other shareholders have a preemptive right to purchase the stock rights to be transferred upon their approval", the preemptive right to purchase targets on "the stock rights to be transferred upon their approval". Here "the stock rights to be transferred upon their approval" are the same thing with the stock rights to be transferred by certain shareholder. Then, the precondition of exercising the preemptive right is the "same condition". Quantity is also one of elements of "same condition". Finally, shareholders are allowed to exercise the preemptive right to purchase partially, it may affect the expected profits of assignor. Suppose a shareholder holds $51 \%$ of company stocks. He or she has the absolute control over the company. The third party wants to get the controlling right and would like to purchase his or her stocks. Under this condition, if other shareholders exercise the preemptive right partially, such as purchasing $10 \%$ of the stock to be transferred, then only $41 \%$ of stocks can be purchased by the third party. As a result, the third party may refuse to purchase at last since it can not get the controlling right. So, the assignor's expected profits are losing.

\section{Regulations in article of association on limited company transferring stock rights}

The fourth term of 72 Article in Company Law regulates: "Unless it is otherwise provided for of the transfer of stock rights in the articles of association, the articles of association shall be followed". Law makers emphasize the adjustment effect of articles of association on the transfer of stock rights in perspective of encouraging company self governance and shareholders self governance.

How to understand this term? For the issue of stock rights transfer, as there is a conflict between the regulations of Company Law and the articles of association, do the articles of association have the priority? Or, with the precondition of following the Company Law, could articles of association embody the wisdom of shareholders and do they have the priority in practice? The author prefers to the later. According to the Article 11 in Company Law and the Article 23 in Rules for Company Register and Management, articles of association are based on laws. Once there are contents betraying the law or administrative regulations, company register agency can ask the company to amend them. Therefore, although articles of association, as the product of interest game of shareholders, embody the self governance of shareholders in essence, articles of association should be regulated by present law. The former exaggerates the effect of articles of association improperly. According to the later, shareholders can embody their wisdom in the transfer of stock rights by articles of association. And articles of association must be exercised in the field of law. In other words, whether the articles of association, especially concerning the transfer of stock rights, are effective or not is based on whether the articles are in accordance with the regulations in Company Law, whether the articles benefit the balance of interests, and whether the articles maintain the people combination of company. On one hand, it is not allowed to 
transfer stock rights unlimitedly since it can destroy the people combination of company, affecting company's stability and development. On the other hand, it is not allowed to stop the transfer of stock rights on the excuse of company's people combination.

In a word, as a contract model, the Company Law has lots of imperfect regulations. Just as what was said by Professor Cheffins: "even the most carefully built restrictions on legal transfer may not be in accordance with the preferences of most shareholders" (Weili Huang, 2006, p155). Therefore, company's rule makers should completely understand the regulations of Company Law, and make articles of association benefiting the transfer of stock rights based on self conditions, which can complementing the imperfect part of Company Law or has the priority over the Company Law in practice.

\section{References}

Huang, Weili. (2006). On the contract arrangement for limited company transferring stock rightss ------ comment on the Article 72 of new Company Law of China and application. Sun Yatsen University Forum. No.26(6). p153, 155.

Wang, Baoshu. (2004). A Draft for Company Law of China. Beijing: Social Sciences Academic Press. p34.

Zhao, Xudong. (2003). Company Law. Beijing: Higher Education Press. p8.

Zhao, Xudong. (2003). Reform and reshape limited company ------ suggestions for amending articles of Company Law. Tribune of Political Science and Law. No.3. p16. 